\title{
MENGGAGAS SPIRIT PERJUMPAAN ANTARA KEUSKUPAN BOGOR DAN UMAT BERAGAMA LAIN
}

Dionnysius Yumaryogustyn Manopo|Graduate Student Faculty of Philosophy

Parahyangan Catholic University Bandung, Indonesia

\section{Abstract:}

Christianity exists within the different religious traditions and Christians are aware of this reality as part of their existence. Especially in Asia, this situation has become a basic context to Christianity and the local churches that requires continuous reflections. In Asian reality, religious plurality is not merely a particular situation, but an important stage in the life of the Christianity, which leads to further reflections and even questioning of its existence among the other religions. The Catholic Church in Bogor (the Diocese of Bogor), Indonesia, is one of the example how the church in Asia is trying to survive and to find its roots within the local context. Thir article is inspired by the Diocese's vision, the documents of Vatican II, and other documents of the Catholic Church, in exploring how the "spirit of encounter" can become a model for the local church to continue to exist within the religious plurality. This spirit invites the local believers to have a committment in giving their attention to the their context and to their social dimension. Through the encounters, the local church attempts to reduce the gaps of communication and to preserve good relationship with people of different religious traditions. Here the church enters the interfaith experience or the experience of togetherness, and the spirit of encounter might help spread the image of the church as a church of relation.

Keywords

local church • religious plurality $\bullet$ spirit of encounter $\bullet$ model $\bullet$ relational church

- Diocese of Bogor 


\section{Pengantar}

Keberagaman merupakan bagian dari kehidupan yang tak dapat disangkal. Keberagaman tentu mengandaikan adanya perbedaan sehingga dalam pelbagai perbedaan itulah pencarian akan keunikan dan otentisitas masing-masing basis muncul sebagai sesuatu yang penting. Salah satu situasi yang dihadapi bersama oleh umat kristiani di Indonesia adalah pluralitas tradisi keagamaan. Situasi plural tradisi keagamaan ini seharusnya merangsang umat beragama untuk melangsungkan dialog demi menerima perbedaan dan meneguhkan keunikan masing-masing. Dewasa ini, sayangnya, pluralitas tradisi keagamaan justru menyisakan perdebatan panjang dalam kehidupan bersama. Alih-alih memungkinkan keterbukaan dan perjumpaan dalam intensitas yang tinggi, pluralitas dalam tradisi keagamaan justru dipandang sebagai kenyataan yang masih sulit diterima oleh banyak pihak, sehingga sering menjadi batu sandungan dalam kehidupan bersama. Meningkatnya tegangan sosio-kultural serta sosio-politik di negara ini sebagaimana sering diberitakan dalam banyak media massa, baik media cetak maupun media daring, menjadi bukti bahwa konflik berbasis agama sudah cukup dalam mempengaruhi dan melukai praksis hidup bermayarakat dan bernegara.

Keuskupan Bogor merupakan instansi keagamaan Gereja Katolik yang berada di wilayah Provinsi Jawa Barat. Sebagai sebuah instansi keagamaan, Keuskupan Bogor berusaha menghadirkan wajah dan peran Gereja Katolik yang mampu mengakomodasi kebutuhan spiritual umat beriman yang berada di wilayah pelayanannya. Dengan demikian, Keuskupan Bogor hadir di wilayah ini sebagai salah satu dari sekian banyak komunitas yang eksis berdasarkan tradisi keagamaan di daerah Jawa Barat dan Banten. Sebagai sebuah komunitas, sudah sewajarnya jika ditumbuhkan rasa solidaritas dan persaudaraan yang tinggi dan mendalam secara internal. Namun, tampaknya mesti terus disadari dan dijaga bahwa Keuskupan Bogor merupakan salah satu komponen dari masyarakat multikultural yang ada di daerah Jawa Barat. Dengan adanya situasi kontras atau pembanding ini, Keuskupan Bogor diingatkan untuk tidak bersikap arogan dan tidak bersikap antipati terhadap mereka yang memiliki latar belakang tradisi keagamaan berbeda dan telah berada lebih dulu di wilayah ini. Sikap berani 
memberikan diri dengan cara memperhatikan pihak yang lain merupakan sebuah langkah antisipatif agar Gereja tidak menjadi komunitas yang tertutup, melainkan selalu terbuka pada lingkungan tempatnya berada.

Fakta yang tak dapat disangkal adalah bahwa Keuskupan Bogor hidup berdampingan dengan saudara-saudari dari komunitas-komunitas berbeda, namun di tanah yang sama. Fakta ini telah berbicara secara konkret dan visual melalui hadirnya (gedung) gereja Katolik yang berdampingan dengan kehadiran fisik tempat-tempat ibadah dari komunitas keagamaan lain. Kedekatan secara ruang menjadi tanda keunikan kehadiran Keuskupan Bogor di wilayah Jawa Barat dan Banten. Kedekatan dalam hal ruang ini mestinya dapat dimanfaatkan dengan maksimal oleh Keuskupan Bogor agar terjalin komunikasi yang mendalam antara umat Katolik dan umat dari tradisi keagamaan yang lain. Oleh karenanya, seruan Paus Fransiskus yang mengatakan bahwa hendaknya Gereja tidak membangun tembok melainkan membangun 'jembatan' akan sangat relevan dan aktual dengan kondisi yang dihadapi oleh Keuskupan Bogor. Berada di wilayah yang sama dengan tradisi keagamaan lain mendorong Gereja Keuskupan Bogor untuk melihat kenyataan ini sebagai suatu kesempatan untuk membangun sebuah perjumpaan dengan "yang lain”.

Saat ini, tantangan yang sedang dihadapi adalah bagaimana cara Gereja Keuskupan Bogor dapat membangun kesadaran bagi umat Katolik agar mau mengusahakan perjumpaan dengan umat dari tradisi keagamaan lainnya. Kesadaran akan pentingnya membangun perjumpaan inilah yang dapat menjadi dasar untuk merealisasikan praksis membangun 'jembatan' dalam kehidupan bersama antaragama. Salah satu dasar yang akan dilihat dalam membangun kesadaran tersebut ialah rumusan visi dan misi Gereja Keuskupan Bogor. Rumusan yang terbentuk pada 2002 ini merupakan pedoman arah dan tujuan yang ingin dicapai oleh Keuskupan Bogor. Meskipun rumusan visi dan misi ini dibentuk oleh Keuskupan Bogor, hasil perumusan itu akan bersifat ad intra, namun juga ad extra. Dengan refleksi lebih lanjut berikut ini, umat Katolik dapat mengetahui bahwa panggilan dan kemauan untuk bertemu saudara-saudari yang berasal dari komunitas berbeda ini dapat dipandang sebagai kunci keberhasilan langkah Keuskupan Bogor untuk mewujudkan secara sempurna visi dan misi yang telah ada. 


\section{Beranjak dari Visi dan Misi Keuskupan Bogor}

Visi dan misi yang telah dicanangkan merupakan patokan bagi Keuskupan Bogor untuk menentukan langkah pastoralnya. Rumusan visi dan misi itu dihasilkan dalam Sinode Keuskupan yang diselenggarakan pada 2002. Istilah 'sinode' sendiri berasal dari bahasa Yunani, yang terdiri atas kata syn yang berarti 'bersama' dan hodos yang berarti 'berjalan'. Dengan kata lain, sinode berarti berjalan bersama menuju satu tujuan atau idealitas tertentu. Dengan definisi 'sinode' tersebut, dapat diketahui bahwa visi dan misi yang telah dicanangkan bukanlah didasarkan pada keinginan pribadi semata, melainkan merupakan sebuah keputusan atau kesepakatan bersama. Lebih lagi, perumusan visi dan misi Keuskupan didasarkan pada hal-hal mendasar yang diyakini sebagai kebenaran iman dan moral. Bagi Keuskupan Bogor, nilai-nilai utama tersebut adalah bahwa setiap orang dipanggil ke dalam kelompok; setiap orang secara pribadi maupun kelompok memiliki tanggung jawab untuk mengembangkan pribadi, Gereja dan masyarakat; setiap orang berhak dan berkewajiban untuk terlibat secara aktif sesuai dengan bentuk hidup dan keadaannya; yang telah diselamatkan berkewajiban menyelamatkan orang lain; Gereja itu menyejarab; Gereja bersifat inkulturatif dengan nilai-nilai setempat; dan Gereja memanfaatkan ilmu dan teknologi. ${ }^{1}$ Demikianlah nilai-nilai utama yang telah dipertimbangkan oleh Keuskupan Bogor untuk membangun visi dan misi bersama dalam peziarahannya di Tatar Sunda.

Melalui serangkaian proses yang cukup panjang, terumuskan visi dan misi Keuskupan Bogor. Visi yang dihasilkan bersama ini terkait tentang ungkapan yang berbunyi: "ingin menjadi Gereja macam apa". Rumusan visi Keuskupan Bogor adalah bahwa Keuskupan Bogor menjadi communio dari aneka komunitas basis yang beriman mendalam, solider dan dialogal, memasyarakat dan misioner. ${ }^{2}$ Misi yang dirumuskan bersama ini menjadi tanda "untuk apa atau alasan keberadaan" dari Keuskupan Bogor. Misi dari Keuskupan Bogor adalah menghadirkan Kerajaan Allah dengan mengabdikan diri secara aktif dalam meningkatkan harkat dan martabat manusia melalui pengelolaan, pengembangan dan pemanfaatan sumber daya. ${ }^{3}$ Dengan demikian, visi dan misi dari Keuskupan Bogor ini hendak menjadi sebuah gerak langkah bersama bagi setiap komunitas umat beriman yang terangkum di dalamnya. Hal ini menjadi penting mengingat komunitas-komunitas yang lebih kecil, baik yang bersifat parokial maupun 
kategorial, merupakan ujung tombak kehadiran Gereja partikular bersama dengan semua komponen masyarakat yang lain. Implementasi visi dan misi dalam ruang lingkup yang lebih terbatas bisa membawa implikasi yang baik, sebab dengan demikian cita-cita itu menjadi lebih kontekstual dan relevan.

Visi dan misi yang telah dilahirkan pada sinode Keuskupan Bogor pada 2002 ini penting untuk selalu direfleksikan kembali terutama dalam terang kehidupan bersama yang berkembang dan berubah. Bagian yang cukup menantang untuk disorot lebih jauh adalah perihal visi yang dimunculkan oleh Keuskupan Bogor. Dari visi yang ingin dicapai ini, setidaknya orang melihat ada tiga komponen yang ingin dicapai. Ketiga komponen ini (komunitas beriman yang mendalam - solider dan dialogal - memasyarakat dan misioner) jika dilihat kembali bukanlah sesuatu yang berdiri sendiri dan terpisah satu sama lain, melainkan sebagai sebuah peristiwa yang mencerminkan pertumbuhan iman yang berkesinambungan. Di antara komponen yang satu dengan yang lainnya, ditunjukkan adanya prasyarat dan keterikatan satu sama lain demi mewujudkan model Gereja yang ideal bagi Keuskupan Bogor.

Dalam terang kehidupan bersama saat ini, visi yang telah terumus pada sinode Keuskupan Bogor 2002 itu dapat menjadi acuan refleksi yang tepat guna dalam menghadirkan wajah Gereja di Jawa Barat. Visi ini hendak mengarahkan komunitas umat beriman Kristiani menjadi sebuah komunitas yang kokoh sekaligus solider. Visi ini mengingatkan pentingnya keseimbangan antara dimensi vertikal dan horizontal dalam kehidupan manusia yang beriman (manusia kristiani). Kedewasaan iman yang hendak dipupuk dan dikembangkan oleh Gereja Keuskupan Bogor adalah proses yang akan berbuah pada kematangan komunitas umat beriman Kristiani sehingga mau dan mampu membangun sebuah perjumpaan dengan yang lainnya. Dengan kata lain, jika kembali melihat visi dan misi yang telah dicanangkan oleh Keuskupan Bogor pada 2002 ini dalam terang relasi hidup bersama saat ini, umat Katolik diundang mengalami perjumpaan dengan yang lain dengan menjadikannya sebuah panggilan bagi Gereja Keuskupan Bogor, agar memperoleh keutuhan wajah Gereja yang ideal seperti yang diharapkan.

Mengingat pentingnya memperhatikan kontinyuitas sejarah Keuskupan Bogor, terutama dalam kurun waktu sejak sinode pada 2002, Mgr. Paskalis 
Bruno Syukur juga mengeluarkan suatu panduan implementasi (Road Map) prioritas kebijakan pastoral Keuskupan Bogor periode 2016-2020. Melalui buku ringkas ini disampaikan bahwa Uskup Bogor mencanangkan 5 prioritas kebijakan dalam penggembalaannya hingga beberapa tahun mendatang. Penyampaian kebijakan pastoral ini dimaksudkan agar semua elemen umat beriman memiliki kesamaan fokus karya pastoral, sehingga diharapkan akan terbantu membangun sinergitas dan hasil yang lebih nyata serta bisa dirasakan secara real. ${ }^{4}$ Kata 'fokus' yang dimaksudkan menunjuk pada kesatuan visi dan misi yang mendasari paroki-paroki dan lembaga-lembaga Katolik yang ada di Keuskupan Bogor serta kesatuan perbatian, sehingga paroki-paroki yang ada senantiasa dapat berjalan bersama. Sementara itu, kata 'sinergitas' menunjuk pada usaha kerja sama di antara paroki-paroki dan lembaga-lembaga Katolik yang ada untuk secara kreatif memperjuangkan kesatuan perhatian yang telah disinggung di atas. Selanjutnya, guna mencapai hasil yang nyata diingatkan agar parokiparoki dan lembaga-lembaga Katolik yang ada harus memperjuangkan perhatian yang ditujukan pada perkembangan umat beriman dan usaha untuk mencapai visi bersama tersebut.

Dalam "Road Map Kebijakan Pastoral" disebutkan bahwa ruang lingkup prioritas program Keuskupan Bogor adalah kebijakan pastoral keluarga, kebijakan pastoral Orang Muda Katolik (OMK), kebijakan pastoral pendidikan, kebijakan pastoral sumber daya manusia (SDM), dan kebijakan pastoral sosial politik dan kemasyarakatan hidup menggereja. ${ }^{5}$ Adanya prioritas program ini tidak bermaksud untuk membatasi inisiatif atau reksa pastoral yang tak termuat di dalamnya. Meskipun secara eksplisit tidak ada prioritas program tentang relasi Gereja dan komunitas keagamaan lain, namun pada bagian kebijakan pastoral sosial politik dan kemasyarakatan hidup menggereja terdapat pokok-pokok yang menarik untuk ditelaah lebih jauh dalam kaitan dengan hal itu.

Titik utama yang ingin disasar dari kebijakan pastoral yang terakhir ini adalah untuk mengajak umat beriman pergi keluar dan mengingat kewajibannya untuk turut memperjuangkan terwujudnya kebaikan untuk semua, terutama bagi yang miskin dan menderita. ${ }^{6}$ Kebijakan pastoral ini mengingatkan bahwa komunitas umat beriman Kristiani tidak pernah tinggal sendiri, namun harus hadir dan bidup di dalam masyarakat, serta 
menunjukkan keunikan komunitas Kristiani, yakni preferensi terhadap yang miskin dan lemah sesuai dengan amanat Injil. Melalui titik inilah Gereja Keuskupan Bogor ditantang untuk berani menampilkan diri, mewartakan dan menghidupi nilai-nilai keimanan, serta berjalan bersama dengan saudara-saudari dari berbagai komunitas yang berbeda.

Dari serangkaian perumusan teoretis wajah dan langkah pastoral bagi Gereja Keuskupan Bogor, dapat dilihat bahwa rumusan tersebut juga menjadi peluang bagi Gereja untuk mengalami perjumpaan dengan yang lain. Kesadaran akan saudara-saudari dari komunitas keagamaan lain selama ini tidak pernah luput dari perhatian Gereja Keuskupan Bogor. Formulasi visi dan misi yang telah ditetapkan oleh Keuskupan Bogor ini dapat membantu mendorong komunitas umat beriman Kristiani yang ada untuk terus menerus membangun relasi dengan sesamanya. Kehadiran dari "yang lain" merupakan rahmat yang pada akhirnya mengundang komunitas umat

beriman Kristiani untuk mewujudkan kepenuhan kehidupan imannya.

\section{Wajah Gereja yang Berelasi}

Konsili Vatikan II merupakan tonggak baru yang membawa banyak perubahan dalam sejarah perjalanan Gereja Katolik. Konsili Ekumenis ke-21 tersebut merupakan sebuah peristiwa yang membawa Gereja Katolik pada paradigma baru dalam menjalankan perannya di dunia. Konsili termutakhir Gereja Katolik ini menjadi sebuah peristiwa yang membangkitkan kesadaran-kesadaran baru dalam berteologi dan merefleksikan iman. Desakan imperatif gemanya mengajak umat beriman untuk beralih dari model teologi yang mengagungkan kemapanan rumusan-rumusan dogmatis metafisis yang cenderung tidak menyentuh hidup manusia, kepada refleksi yang bertolak dari pengalaman konkret eksistensial dan fenomenologis kehidupan beriman. ${ }^{7}$ Titik tolak baru yang sangat berpengaruh yakni pengalaman konkret umat beriman, dan inilah yang kemudian mengisi ruang-ruang pada dokumen-dokumen yang dihasilkan Konsili Vatikan II dan seruan-seruan para paus setelahnya.

Salah satu prestasi gemilang yang dilahirkan oleh Konsili Vatikan II adalah pembaharuan pandangan akan Gereja dari institusi keselamatan menjadi sarana keselamatan. Pembaharuan pandangan ini merevisi pandangan lama yang mengatakan bahwa Gereja Kristus adalah (est) Gereja Katolik, menjadi Gereja Kristus yang berada (subsistit in) dalam 
Gereja Katolik. ${ }^{8}$ Pandangan baru ini tertuang secara eksplisit pada dokumen Lumen Gentium. Pandangan Gereja mengenai dirinya sendiri dalam dokumen Lumen Gentium ini juga turut membahas mengenai hubungan Gereja dengan umat Kristen bukan Katolik, dan umat beragama lain yang bukan Kristiani. Dikatakan di dalam dokumen bahwa Gereja tidak dapat menghindari kenyataan ini dan karena banyak alasan akan selalu berhubungan dengan mereka. Juga, diharapkan bahwa Gereja senantiasa berdoa, berharap dan berusaha, serta mendorong para putranya untuk memurnikan dan membarui diri supaya tanda Kristus dengan lebih cemerlang bersinar pada wajah Gereja. ${ }^{9}$ Perubahan ini membawa suatu konsekuensi teologis dalam kehidupan menggereja dan juga dalam relasi dengan yang lain. Pandangan baru mengenai Gereja ini mengarahkan Gereja Katolik untuk tidak hanya mengklaim keselamatan pada dirinya sendiri, serta lebih menghormati dan terbuka terhadap karya Allah melalui tradisi keagamaan yang lain. Beberapa teolog kristiani dewasa ini menarik kesimpulan bahwa teologi pun tidak dapat dirumuskan secara terpisah dari teologi agama-agama lain, dan bahwa sesungguhnya perkembangan teologi kristiani di masa yang akan datang merupakan hasil langsung dari dialog yang serius dengan tradisi keagamaan yang lain. ${ }^{10}$

Gereja juga memiliki dasar-dasar historis dan teologis dalam usahanya membangun relasi dengan tradisi keagamaan lain. ${ }^{11}$ Dasar historis tersebut adalah tumbuhnya kesadaran baru pada kurun waktu dewasa ini bahwa umat manusia semakin hari semakin erat dipersatukan dan hubungan antarbangsa semakin meningkat. Salah satu sebab eratnya hubungan antarbangsa itu ialah kemajuan di bidang informasi, yang diakui sebagai wujud baru kesatuan yang makin erat antarmanusia. Dasar historis yang kedua adalah bahwa Gereja secara serius dan tulus mengajak bangsa manusia untuk menjalin rekonsiliasi. Dasar historis yang ketiga ialah dialog interreligius berkaitan dengan pengalaman hidup konkret di tengah umat beriman lain. Umat Kristen yang hidup di tengah masyarakat majemuk tidak mungkin mengambil jarak dari realitas kehidupan bersama yang lain. Lagipula, ciri khas paling langsung dari masyarakat majemuk adalah kehidupannya yang bersifat dialogal. Dasar historis keempat ialah perkembangan kebudayaan yang semakin pesat dan semakin mudah dikenali oleh pihak lain. Sedangkan dasar-dasar teologisnya: pertama, penegasan peran Gereja sebagai sakramen keselamatan dalam meningkatkan 
kesatuan dan persatuan umat manusia semakin konkret (ekklesiologis); kedua, keyakinan Gereja akan misteri kesatuan umat manusia yang berakar pada Allah yang sama, sebagai asal usul sekaligus tujuan pengembaraan (teologis trinitarian); ketiga, pengakuan Gereja akan peran agama-agama yang semakin menampakkan kepentingannya dalam kehidupan manusia (gagasan teologis tentang agama-agama); dan bagian lain yang dapat ditambahkan, yakni paham universalitas rencana keselamatan Allah.

Berdasarkan kesadaran baru yang dicetuskan oleh Konsili Vatikan II, keutamaan Gereja lebih dari sekadar berdasarkan catatan sejarah yang menunjukkan pentingnya pertobatan jiwa-jiwa (conversio animarum) dan pendirian Gereja (plantatio ecclesiae). Hal yang tidak dapat diabaikan adalah kemauan Gereja untuk membangun relasi dengan lingkungan sekitarnya. Jacques Dupuis mengungkapkan bahwa sikap Gereja terhadap penganut agama lain berhubungan erat dengan pengakuan adanya bagian-bagian dari nilai positif yang dapat ditemukan di dalam tradisi keagamaan yang lain. ${ }^{12}$ Gereja perlu memulihkan kontak-kontak yang putus dengan dunia luar dan menerima dialog dengan komunitas-komunitas keagamaan yang lain sebagai sikap dasar. ${ }^{13}$ Sikap dasar ini hendaknya tidak didasari oleh tuntutan atau keterpaksaan, melainkan merupakan buah dari evolusi kesadaran spiritual yang harus terus digaungkan dan disebarkan kepada segenap umat beriman.

Di era multikultural seperti saat ini, kata 'misi' menjadi sebuah kata yang riskan untuk digunakan di dalam kehidupan bersama. Tak jarang istilah misi diasosiasikan dengan usaha menundukkan mereka yang tidak dalam kesatuan dengan komunitas serta usaha untuk mempertobatkan mereka. Potret protes dari masyarakat terhadap keberadaan beberapa gereja di wilayah pastoral Keuskupan Bogor menjadi bukti bahwa Gereja belum cukup memasyarakat. Protes tersebut menunjukkan adanya kesenjangan antara Gereja dan masyarakat sekitar sehingga mengakibatkan miskomunikasi di antara pihak-pihak yang terkait dengan keberadaan komunitas gerejawi. Kesenjangan yang terus-menerus dibiarkan akan terus menciptakan potensi ruang konflik antara Gereja dan pihak lain. Di hadapan kenyataan yang demikian, pertanyaan penting adalah apakah Keuskupan Bogor masih bisa menjalankan misi di wilayah pastoralnya? Jika diartikan sebatas mempertobatkan orang dan pembaptisan belaka, 
misi yang demikian tidak dapat dilaksanakan, karena hanya akan membuat situasi hidup bersama semakin tidak kondusif dan pada akhirnya mengacaukan kehidupan bersama. Demikian pula, dalam situasi seperti itu potensi-potensi konflik tidak bisa begitu saja diatasi dengan melibatkan pihak atau dengan menggunakan struktur-struktur asing. Keadaan tersebut harus diantisipasi dengan memanfaatkan potensi-potensi religius dan budaya yang sudah tersedia, termasuk potensi yang terdapat pada agama Kristiani. ${ }^{14}$ Oleh karena itu, Keuskupan Bogor memaknai 'misi' di era multikultural ini sebagai suatu kesempatan dan kehendak untuk membangun relasiyang tulus dengan masyarakat yang berasal dari tradisi-tradisi keagamaan lain. Dengan demikian, menjalankan misi dengan cara baru seperti ini akan membuka peluang bagi siapapun untuk menjalani bidup bersama dengan baik serta turut membantu dan mengembangkan satu sama lain.

Ketika mengusahakan misi Gereja melalui pembangunan relasi, Gereja Keuskupan Bogor dapat menimba inspirasi dari Seruan Apostolik Evangelii Gaudium (2013) yang dikeluarkan oleh Paus Fransiskus. Dokumen ini menekankan bahwa alasan mendasar bagi umat beriman untuk pergi keluar adalah sukacita karena mengalami perjumpaan dengan Yesus. ${ }^{15}$ Paus Benediktus XVI melalui ensiklik Deus Caritas Est (2005) juga pernah menegaskan hal yang sama, yakni bahwa menjadi seorang kristiani bukanlah hasil dari pilihan etis atau gagasan mulia, melainkan karena perjumpaan dengan suatu kejadian, seseorang yang memberikan cakrawala baru dan arah yang menentukan dalam hidup. ${ }^{16}$ Pengalaman transformasi personal inilah yang kemudian dapat menghantarkan umat beriman untuk mau berjumpa dengan pihak lain. Membangun relasi dengan sesama tidak dapat dimulai dengan memaksa pihak lain untuk menjadi seorang Kristen, namun lebih berarti bahwa umat kristiani diajak untuk senantiasa membagikan sukacita yang mereka alami. Adanya sukacita dan keinginan untuk membangun relasi merupakan dua hal yang tidak bisa dipisahkan. Kedua hal tersebut lahir dari hubungan sebab-akibat. Mengalami sukacita dengan menghilangkan keinginan untuk membangun relasi adalah sama dengan menghapus sukacita yang ada di dalam diri. Dengan dua prinsip tersebut umat kristiani dapat berusaha membangun relasi dengan tanpa beban dan menjadikan kesaksian hidupnya sebagai model hidup beriman yang menginspirasi kehidupan bersama umat beragama lain. 
Pada akhirnya, Gereja Keuskupan Bogor akan harus menyadari bahwa keberadaannya tidak dapat dipisahkan dengan realitas yang sudah ada di sekitarnya. Dengan menyadari betapa pentingnya keberadaan dari yang lain bagi pertumbuhan dan kelangsungan kehidupan Gereja, Keuskupan Bogor akan memasuki sebuah proses dialektis. Proses dialektis ini melibatkan Gereja dan dunia sekitarnya, dan ini bisa menghantarkan kedua belah pihak hingga sampai pada tahap saling memperkaya dan saling mentransformasi. Dalam proses dialektis tersebut, Gereja juga dapat mendeteksi kehadiran Allah melalui aspirasi dan keyakinan orang lain. ${ }^{17}$ Keterbukaan pada aspirasi dari pihak lain juga dapat membantu Gereja Keuskupan Bogor untuk menerima dan menghayati kenyataan multikultural yang menjadi konteks keberadaannya. Gereja dalam keadaan ini tidak bisa menghindari dunia, namun justru sebaliknya, membutuhkan dunia untuk dapat menjadi komunitas gerejawi yang sejati. ${ }^{18}$ Eksplorasi atas visi dan misi ini dapat menegaskan bahwa dimensi persekutuan dan dimensi perutusan memang adalah dua dimensi yang saling terkait secara mendalam. ${ }^{19}$

\section{Perjumpaan dalam Dialog}

Usaha untuk membangun relasi yang sejati harus diikuti dengan usaha untuk mengalami perjumpaan satu sama lain. Pada era kemajuan teknologi informasi seperti saat ini, godaan terbesar bagi manusia adalah mengalami 'perjumpaan' semu di dunia maya, melalui beragam media sosial dan kecanggihannya yang seolah-olah memungkinkan interaksi tanpa batas kepada siapapun, kapanpun, dan di manapun. ${ }^{20}$ Kemajuan teknologi itu membuat seolah-olah dunia berada di dalam genggaman dan 'perjumpaan' yang diyakini hanyalah sejauh sentuhan jari. Fenomena ini telah membuat nyaman banyak pihak dalam jangka waktu yang cukup lama. Akan tetapi, Gereja dipanggil untuk tetap bersikap kritis terhadap kemajuan teknologi, meskipun kemajuan itu menawarkan kemudahan dalam banyak aspek. Hal yang mesti ditekankan ialah bahwa 'perjumpaan' di dunia maya tidak benar-benar real. 'Perjumpaan' yang dimungkinkan oleh kemajuan teknologi pun tidak sepenuhnya bermakna perjumpaan. Melalui kemajuan teknologi, perjumpaan justru selalu sudah direduksi menjadi komunikasi yang impersonal karena tidak menghadirkan pribadi-pribadi yang bertemu secara konkret. 
Perjumpaan yang diharapkan dalam misi membangun relasi adalah perjumpaan yang diartikan berupa perjumpaan fisik di antara warga Gereja dan umat beragama lain. Perjumpaan secara fisik ini mewakili perjumpaan dengan seluruh afeksi personal yang sampai kini kurang dapat terkomunikasikan dengan baik oleh media sosial beserta kecanggihannya. Melalui perjumpaan langsung ini, umat kristiani didorong untuk mampu berpikir, bertutur, serta bertindak melampaui dirinya, karena mengalami secara langsung kontak dengan sesama, yang memang menunjukkan adanya perbedaan. Melalui perjumpaan seperti ini pula terbukalah "ruangruang baru" pada pihak-pihak yang terlibat untuk juga memulai sesuatu yang baru dalam peziarahan hidup bersama, yakni sebuah dialog. ${ }^{21}$ Peristiwa perjumpaan real menjadi simbol penghormatan bagi sesama, sehingga mengandaikan adanya sikap saling mengakui dan menerima kenyataan tentang pihak lain sebagai bagian dari suatu realitas pluralistik, yang memang sudah selalu ada dalam kehidupan. Momen perjumpaan seperti ini dapat menjadi momen awal suatu transformasi bersama, yang diharapkan dapat membawa semua pihak menuju kebaikan bersama (bonum commune).

Perjumpaan memungkinkan setiap manusia untuk memasuki tahap baru yakni dialog dengan "yang lain". Sebuah dialog berarti sebuah diskusi yang jujur antara dua orang (atau lebih) yang mempunyai keyakinan yang berbeda, dengan harapan mencapai kesepakatan atau sekurang-kurang mendekatinya. ${ }^{22}$ Dalam definisi yang lain, menurut Paul F. Knitter, dialog adalah pertukaran pengalaman dan pemahaman di antara dua orang atau lebih yang dimaksudkan agar semua pihak yang berpartisipasi dapat bertumbuh di dalam pengalaman tersebut serta memperoleh pemahaman baru..$^{23}$ Sementara itu, menurut Harold A. Netland, dialog adalah satu cara untuk secara serius menganggap orang lain sebagai sesama manusia. Dialog dalam hal ini juga sekaligus merupakan lambang kerendahan hati, sensitivitas, dan keramahan terhadap umat beragama lain. ${ }^{24}$ Tujuan dari semua pengertian dialog tersebut terutama ialah saling pengertian dalam usaha mencoba memahami yang lain dengan cara sebagaimana seseorang ingin dimengerti. Tujuan selanjutnya adalah pengavaan bersama yang berarti bahwa di dalam dialog tidak ada lagi persaingan, dan ketika hubungan tersebut bersifat positif, hal itu akan membawa sebentuk kekaguman yang mendalam atas pandangan atau agama orang lain, serta juga pada agama diri sendiri. ${ }^{25}$ Berbagai pemahaman dan tujuan dialog ini mengerucut pada suatu 
penegasan bahwa dialog bukanlah sekadar usaha bagi kaum 'minoritas' untuk mencapai rasa aman. Bagi Gereja, upaya dialog dengan yang lain merupakan sebuah panggilan perjumpaan untuk senantiasa membangun relasi dengan dunia.

Pengertian dialog menurut Gereja Katolik tecermin dalam pernyataan Kardinal Jean Louis Tauran, Presiden Dewan Kepausan untuk Dialog Antaragama. ${ }^{26}$ Ia mengatakan bahwa dialog itu terjadi di antara orangorang yang beriman dan oleh karena itu bukanlah dialog di antara agamaagama, melainkan di antara orang-orang yang konkret. Ia menjelaskan bahwa sebuah dialog terjadi di antara orang-orang yang meyakini agamaagama yang berbeda, dan yang bertujuan untuk mengenal satu sama lain dan bertukar hadiah spiritual, menghormati kebebasan hati nurani, menghindari proselitisme dan mengedepankan kesaksian-kesaksian iman yang tulus. Demikian juga, dalam dialog masing-masing pihak perlu sepakat untuk tidak melepaskan keyakinannya, tetapi membiarkan dirinya ditantang untuk mempertimbangkan problem-problem yang berbeda dari persoalanpersoalan di masyarakat, berharap untuk mendapatkan pengetahuan yang lebih lanjut untuk melihat agama lain dengan objektivitas, dan memperkaya kehidupan spiritualnya sendiri dengan unsur-unsur positif yang diperoleh dari umat beragama lain.

Sering dijumpai bahwa kesulitan untuk memulai dialog disebabkan munculnya anggapan bahwa dialog disamakan dengan tukar-menukar informasi keagamaan, terlebih terkait ajaran dari masing-masing agama itu sendiri. Salah satu implikasi pengertian seperti ini adalah timbulnya sikap 'inferior' pada sebagian besar umat beriman untuk mau 'ke luar' dan berdialog dengan yang lain. Dialog seakan-akan dipercayakan kepada kaum intelektual semata. Hal ini tidak tepat. Dialog tidak bisa dilakukan sebatas pada tataran intelektual semata. Selain bertukar informasi dan pengetahuan tentang ajaran, dialog juga dapat dikembangkan hingga menjadi dialog kehidupan, dialog karya, dan dialog pengalaman keagamaan. ${ }^{27}$ Ragam cara dialog yang sebetulnya bisa dikembangkan ini dapat mendorong setiap umat Katolik untuk berpartisipasi dan terlibat sesuai dengan motivasi dan kemampuan masing-masing. Keragaman cara berdialog perlu disosialisasikan untuk menghantar umat beriman pada tujuan dialog itu sendiri, yang menurut Knitter, adalah pertobatan. Perlu diperjelas bahwa pertobatan yang dimaksud di sini adalah perubahan 
paradigma dari menguasai atau menang terhadap yang lain menuju paradigma berbagi (sharing) ${ }^{28}$ "Paradigma berbagi" inilah model yang cocok bagi umat kristiani terutama berkaitan dengan cara hidup mereka sebagai saksi-saksi yang ingin membagikan pengalaman sukacita yang dialami karena berjumpa dengan Yesus Kristus.

Sampai pada titik ini, dialog menjadi sangat penting bagi umat Katolik karena merupakan sarana untuk mengalami perjumpaan dengan pihak lain dan mengalami transformasi diri, serta bukan untuk mentransformasi iman pihak lain. Peristiwa perjumpaan pada akhirnya menjadi titik gravitasi bagi umat Katolik, dan dalam hal ini sangat relevan bagi umat Katolik di Keuskupan Bogor, sehingga setiap peristiwa perjumpaan dengan pihak yang lain ini akan 'mengatasi' usaha-usaha untuk berdialog. Pernyataan ini tidak bermakna bahwa dialog menjadi sesuatu yang tidak penting atau esensial lagi dalam kehidupan bersama. Dialog tetap merupakan hal yang berguna sesuai perannya, namun sekalipun usaha untuk berdialog tidak dapat berjalan dengan baik, pengalaman perjumpaan itu sendiri telah memberikan buah-buah tersendiri kepada umat kristiani. Kebuntuan maupun kegagalan dalam dialog merupakan hal yang bisa terjadi ketika mengusahakan proses dialektis antara Gereja dan pihak-pihak lain. Pengalaman jatuh ini tidak perlu membuat umat Katolik takut dan kemudian berhenti mengusahakan perjumpaan dengan umat yang berasal dari komunitas keagamaan yang berbeda. Meskipun mengalami kebuntuan atau kegagalan, Gereja seharusnya tetap berusaha menghidupkan semangat perjumpaan dengan siapapun, sebab melalui perjumpaan (yang barangkali hanya sesaat) umat beriman dari masing-masing tradisi keagamaan sebetulnya sedang membangun "pengalaman bersama" (interreligious experience of togetherness). ${ }^{29}$ Oleh karena alasan inilah, perjumpaan dengan pihak lain sebetulnya merupakan sebuah pemurnian identitas dan sekaligus kebutuhan, dan karenanya adalah sangat relevan bagi kehidupan Gereja di masa kini.

"Pengalaman bersama" dengan pihak lain tersebut bukanlah sebuah pengalaman yang diletakkan di bawah payung tradisi keagamaan tertentu. Pengalaman bersama dengan pihak lain merupakan sebuah pengalaman kehadiran dan partisipasi umat beriman dalam konteks tertentu, dengan menyertakan segala situasi, keprihatinan, dan permasalahan yang ada di dalamnya. Pengalaman kebersamaan dengan pihak lain ini akan mengantarkan setiap umat beriman pada pemahaman yang lebih mendalam, 
yakni kebersamaan yang lebih dari sekadar pemahaman intelektual. Dalam pengertian ini, setiap umat beriman dapat diandaikan mengalami pertumbuhan dalam sikap saling mengerti dan saling menerima, kendati ada kesadaran bahwa mereka pun saling berbeda satu sama lain. Manfaat yang diperoleh melalui pengalaman kebersamaan ini berasal dari kedalaman dan kepekaan hati umat beriman terhadap pihak yang dipandang 'berbeda' dari dirinya. Seruan Apostolik Evangelii Gaudium dapat dirujuk kembali untuk menyimpulkan pembahasan di atas sebagai berikut.

"Hanya melalui perjumpaan - atau perjumpaan yang diperbarui dengan kasih Allah ini, yang berkembang dalam suatu persahabatan yang memperkava, kita dibebaskan dari kesempitan dan keterkungkungan diri. Kita menjadi manusia sepenuhnya ketika kita menjadi lebih dari manusiawi, ketika kita membiarkan Allah membawa kita melampaui diri kita sendiri supaya mencapai kepenuhan kebenaran dari keberadaan kita". 30

\section{Gerak Keuskupan Bogor}

Dengan berpatokan pada visi dan misi, konteks yang dihadapi, serta juga dengan terinspirasi oleh dokumen-dokumen Gereja Katolik, Gereja Keuskupan Bogor akan dapat mengusahakan secara bersungguh-sungguh spirit perjumpaan dengan umat beragama lain di wilayah pastoralnya. Jika hendak menjaga konsistensi dengan apa yang sudah dicanangkan dan disepakati bersama, Gereja Keuskupan Bogor tidak akan tenggelam dalam sebuah refleksi yang sifatnya "ke dalam" saja, namun mengarahkan tanggapan dan tindakannya "ke luar". Mengusahakan spirit perjumpaan dan membangun relasi dengan pihak lain merupakan cara-cara yang tak bisa diabaikan guna mencapai kepenuhan visi dan misi Keuskupan Bogor. Situasi yang kini dihadapi mendesak Gereja Keuskupan Bogor melihat usaha untuk membangun persaudaraan dengan komunitas keagamaan lain tidak sebagai sebuah 'program' tambahan semata, namun menjadi sebuah cara berada yang memberi kerangka bagi program-program lain. Dengan demikian, Gereja Keuskupan Bogor akan dapat berproses menuju sebuah komunitas umat beriman yang kokoh, sekaligus tetap menjadi Gereja yang memasyarakat, yakni yang tidak terpisah dari konteks keberadaannya di Jawa Barat.

Langkah perwujudan visi dan misi yang perlu ditempuh oleh Gereja Keuskupan Bogor, karenanya, adalah menggerakkan setiap elemen, baik 
kategorial maupun parokial, yang bernaung di bawah payung Keuskupan Bogor untuk mengejawantahkan Gereja yang berelasi dalam konteks sosioreligius yang plural lingkungannya. Setiap elemen tersebut perlu mengalami reorientasi keberadaannya dalam relasi dengan lingkungan sekitarnya, agar tetap berusaha supaya Gereja tidak terpisahkan dari lingkungan sekitarnya itu. Penyegaran kesadaran ini perlu senantiasa dijaga karena untuk mewujudkan Gereja yang berelasi diperlukan komitmen dari elemenelemen tersebut untuk berinisiatif dan bergerak. Langkah ini merupakan langkah awal yang harus ditempuh karena spirit perjumpaan ini hanya dapat dilaksanakan terutama oleh komunitas-komunitas yang real, dimulai dari skala dan komunitas kecil, serta menjadi gerakan yang berjalan perlahan tapi pasti di level akar rumput. Keuskupan Bogor, melalui komitmen dari elemen kategorial maupun parokial, dapat berusaha mewujudkan Gereja yang hadir pada suatu tempat dan lingkungan yang khusus, dan dengan demikian wujud Gereja menjadi real dan dialami dalam keseharian hidup. ${ }^{31}$

Keuskupan Bogor mempunyai beberapa agenda internal yang mengarahkan perjumpaan, baik bagi kaum klerus dan biarawan-biarawati maupun bagi umat beriman Katolik umum. Dalam hal ini Keuskupan Bogor dapat mengusahakan dan memperluas agenda tersebut sehingga mewujudkan pula perjumpaan yang bersifat lintasagama. Usaha ini akan menjadi tanda bahwa Gereja Keuskupan Bogor mempunyai kesungguhan dalam membangun relasi serta ingin merangkul sesama serta membawa semua pihak ke dalam peristiwa perjumpaan. Gereja Keuskupan Bogor dengan demikian tidak bertumbuh sebagai sebuah komunitas yang 'eksklusif', namun justru sebaliknya, bertumbuh sebagai promotor "pengalaman kebersamaan" antaragama. Dalam pengertian ini, 'promotor' bukanlah sekadar pihak yang mengumpulkan dan menggerakkan, namun juga pihak yang senantiasa memiliki komitmen dalam spirit perjumpaan. Salah satu karakter yang diperlukan untuk mewujudkan spirit perjumpaan adalah dimensi kontinyuitas atau keberlangsungan secara terus-menerus peristiwa perjumpaan tersebut. Dengan intensitas yang cukup, perjumpaan diharapkan membawa setiap pihak yang terlibat pada rasa persaudaraan vang mendalam. Evangelii Gaudium mengajak umat Katolik untuk menjadi komunitas yang mewartakan Injil dan siap 'menemani' - menemani kemanusiaan dalam seluruh prosesnya, betapapun sulit dan lamanya proses yang harus dijalani. Komunitas seperti ini mestinya terbiasa dengan 
penantian yang memang memerlukan kesabaran dan daya tahan kerasulan. ${ }^{32}$

Agenda perjumpaan yang melibatkan berbagai komunitas tradisi keagamaan perlu diperkenalkan dan melibatkan kaum muda dengan porsi yang tepat. Kaum muda yang menjadikan spirit perjumpaan sebagai basis hidupnya akan memiliki pengalaman kebersamaan yang lebih luas. Kaum muda tersebut akan menjadi tanda generasi masa depan yang mampu menerima perbedaan dan tidak memandangnya sebagai problem yang menghambat kehidupan bersama. Perbedaan dalam terang visi dan misi Keuskupan Bogor, adalah kesempatan. Pembelajaran semenjak dini perihal menjadi saksi dan kemauan untuk mendengarkan akan menjadi bekal yang berguna bagi kaum muda untuk terus melanjutkan spirit perjumpaan. Dengan melibatkan kaum muda, Gereja Keuskupan Bogor dapat mengantisipasi dan memutus rantai kekakuan relasi antara Gereja dan masyarakat sekitarnya.

\section{Simpulan: Gereja yang Mengakar}

Potret ironi yang dihadapi oleh Gereja di Asia ialah bahwa ia masih dianggap sebagai sesuatu yang asing di tengah lingkungannya. Salah satu alasan penting mengapa dianggap asing ialah karena Gereja setempat di Asia pada umumnya menjaga jarak terhadap arus utama kehidupan rakyat, sejarah, perjuangan-perjuangan, dan impian-impian mereka. ${ }^{33}$ Gereja belum berhasil menyatu dengan masyarakat. Henri de Lubac pernah mengungkapkan bahwa banyak umat kristiani yang masih beranggapan bahwa menjadi warga Gereja berarti melepaskan diri dari dunia. ${ }^{34}$ Pandangan seperti ini akan membentangkan jarak antara umat kristiani dan masyarakat sekitarnya. Pandangan itu juga membuat umat kristiani cenderung menyibukkan diri dalam relasi pribadinya dengan Allah dan melupakan dimensi sosial dari identitas kristianinya.

Pengalaman hidup bersama yang didalami melalui visi dan misi Keuskupan Bogor merupakan wajah pengalaman universal yang dialami oleh Gereja Katolik. Setiap komunitas gerejawi selalu berada di tanah yang unik serta memiliki tantangannya masing-masing dan ia akan senantiasa dipanggil untuk berdialog dengan konteks keberadaannya. Oleh karenanya, Gereja tidak dapat dilihat sebagai sekadar sesuatu yang ditempelkan pada kehidupan masyarakat di wilayah tertentu. Gereja perlu hadir sebagai sebuah komunitas yang mengakar, yang mempengaruhi dan 
sekaligus dipengaruhi oleh konteks keberadaannya. Dalam hal ini, spirit perjumpaan demi membangun relasi dengan lingkungan sekitar merupakan suatu tuntutan yang tak terelakkan cara hidup menggereja di wilayah plural ini. Aloysius Pieris pernah menegaskan bahwa ciri kehidupan iman yang dialogal umat Allah merupakan tuntutan mutlak agar dapat dikembangkan Gereja setempat yang sungguh-sungguh otentik. ${ }^{35}$

Pilihan sikap untuk mau terbuka dan membangun relasi dengan umat beragama lain merupakan bentuk dialektis yang dapat terus diusahakan dan dikembangkan oleh Gereja. Gerak timbal balik ini menjadi penanda bahwa Gereja bukanlah sebuah realitas yang sudah jadi, tertutup, atau statis, melainkan realitas yang terus-menerus mencari penyempurnaan serta terbuka pada perubahan yang terjadi. Gereja, meskipun bersifat universal, tidak bisa melupakan sifatnya yang akan selalu terikat pada partikularitas. Oleh karena itu, Gereja memiliki kewajiban untuk selalu berpartisipasi di wilayah publik, agar tidak terjadi kesenjangan di antara komunitas kristiani dan komunitas-komunitas lainnya. Sejalan dengan hal ini, Robert J. Schreiter mengatakan bahwa perwujudan Gereja yang otentik merupakan buah dialogal antara tradisi dan relevansi. ${ }^{36}$ Secara khusus di Indonesia, membangun relasi melalui perjumpaan dalam dialog dengan agama-agama lain merupakan jalan yang diperlukan bagi Gereja Katolik agar mampu hidup dan bertumbuh di 'tanah' yang unik itu. Dialog antaragama adalah penting mengingat vitalnya peran agama bagi masyarakat di Indonesia dan di Asia. Dialog yang baik ini akan mendukung keberlangsungan perjumpaan yang real antara umat beriman Katolik dan umat beriman dari komunitas keagamaan lainnya. Selain itu, Gereja perlu berkomitmen dan bersikap proaktif dalam mengusahakan hal-hal yang baik demi kehidupan bersama. Dengan spirit perjumpaan ini, Gereja tidak lagi menunggu ajakan dari pihak lain atau bersikap pasif, tapi didorong untuk menjadi promotor dalam mengusahakan proses dialogal tersebut. Gereja, bersama dengan pihakpihak lain, perlu bersikap proaktif mengusahakan agar tercipta konteks yang kondusif sehingga mendukung kehidupan bersama.

Pada dasarnya Gereja adalah kumpulan umat beriman kristiani. Umat beriman tersebut memiliki cara hidup dan peran yang berbeda-beda, namun memiliki tanggung jawab yang sama demi bertumbuh dan berkembangnya Gereja. Tugas untuk membangun relasi dengan sesama bukanlah tugas hierarki atau para pemimpin, namun merupakan tugas yang diemban oleh 
segenap umat beriman. Sejauh tanggung jawab perutusan dialog ada pada Gereja lokal, maka orang-orang beriman kristiani harus terlibat dalam perutusan dialog interreligius. Masa depan dialog interreligus berada di tempat pertama pada kaum awam. ${ }^{37}$ Pernyataan ini bukan dimaksud untuk mengalihkan peran begitu saja kepada kaum awam, melainkan untuk mempromosikan spirit perjumpaan yang diusung dalam eksplorasi tulisan ini, agar dapat menjadi sebuah gerakan bersama dan serentak, yang melibatkan segenap umat beriman dan merangkul semua pihak.

\section{References:}

Baum, Gregory. Ecclesiology and Postmodernity: Questions for the Church in Our Time. Minnesota: Liturgical Press. 1970.

Benediktus XVI. Deus Caritas Est. Jakarta: Departemen Dokumentasi dan Penerangan Konferensi Waligereja Indonesia. 2005.

Collins, Gerrard O. \& Farrugia, Edward G. Kamus Teologi. Yogyakarta: Kanisius. 1996.

Dokumen Sidang-Sidang Federasi Konferensi-Konferensi Para Uskup Se-Asia. Jakarta: Departemen Dokumentasi dan Penerangan Konferensi Waligereja Indonesia. 1997.

Dupuis, Jacques. Christianity and The Religions. Maryknoll: Orbis Books. 2002.

Fransiskus. Evangelii Gaudium. Jakarta: Departemen Dokumentasi dan Penerangan Konferensi Waligereja Indonesia. 2013.

Knitter, Paul F. No Other Name?. London: SCM Press. 1990. Pengantar Teologi Agama-Agama. Yogyakarta: Kanisius. 2008.

Panduan Implementasi "Road Map" Prioritas Kebijakan Pastoral Keuskupan Bogor. Bogor, 2016.

Paulus VI. Inter-Mirifica. Jakarta: Departemen Dokumentasi dan Penerangan Konferensi Waligereja Indonesia. 2013.

Philips, Gerardette. Melampaui Pluralisme. Malang: Madani. 2016.

Riyanto, CM, F.X. Armada. Dialog Agama dalam Pandangan Gereja Katolik. Yogyakarta: Kanisius. 1995.

Samosir, Dr. Leonardus. Agama dengan Dua Wajah. Jakarta: Obor. 2010.

Surianto, Agustinus (Ed.). Keuskupan Bogor Menatap Masa Depan. Bogor: Grafika Mardi Yuana. 2002. 


\section{Endnotes:}

1 Bdk. Agustinus Surianto (Ed.), Keuskupan Bogor Menatap Masa Depan (Bogor: Grafika Mardi Yuana, 2002) 187-189.

2 Ibid., 194.

3 Ibid., 195.

4 Bdk. Panduan Implementasi "Road Map" Prioritas Kebijakan Pastoral Keuskupan Bogor (Bogor, 2016) 9.

5 Ibid., 10.

6 Ibid., 31.

7 F.X. Armada Riyanto, CM, Dialog Agama dalam Pandangan Gereja Katolike (Yogyakarta: F.X. Armada Riyanto,

$8 \quad$ Ibid., 98.

9 Bdk. Paulus VI, Lumen Gentium (Jakarta: Departemen Dokumentasi dan Penerangan Konferensi Waligereja Indonesia, 2013) 90-91.

10 Gerardette Philips, Melampaui Pluralisme (Malang: Madani, 2016) viii.

11 Riyanto, op.cit., 155-157.

12 Jacques Dupuis, Chistianity and the Religions (Maryknoll: Orbis Books, 2002) 218.

13 Philips, loc.cit.

14 Dokumen Sidang-Sidang Federasi Konferensi-Konferensi Para Uskup Se-Asia, (Jakarta: Departemen Dokumentasi dan Penerangan Konferensi Waligereja Indonesia, 1997) 312.

15 Fransiskus, Evangelii Gaudium (Jakarta: Departemen Dokumentasi dan Penerangan Konferensi Waligereja Indonesia, 2013) 7.

16 Benediktus XVI, Deus Caritas Est (Jakarta: Departemen Dokumentasi dan Penerangan Konferensi Waligereja Indonesia, 2005) 7.

17 Gregory Baum, Ecclesiology and Postmodernity: Questions for the Church in Our Time (Minnesota: Liturgical Press, 1970) 140.

18 Ibid., 144.

19 Fransiskus, op,cit., 19.

20 Paulus VI, Inter Mirifica (Jakarta: Departemen Dokumentasi dan Penerangan Konferensi Waligereja Indonesia, 2013) 53.

21 Bdk. Kisah Para Rasul 8:26-40.

22 Gerrard O. Collins dan Edward G. Farrugia, Kamus Teologi Yogyakarta: Kanisius, 1996) 53 .

23 Paul F. Knitter, No Other Name? (London; SCM Press, 1985) 207.

24 Paul F. Knitter, Pengantar Teologi Agama-Agama (Yogvakarta: Kanisius, 2008) 46

25 Philips, op.cit., 47.

26 Ibid., 56.

27 Bdk. Riyanto, op.cit., 111-113.

28 Paul F. Knitter, Death or Dialogue (London: SCM Press, 1990) 23.

29 Bdk. Surianto (Ed.), op,cit., 158. 
30 Fransiskus, op,cit., 11

31 Ibid., 24

32 Ibid,

33 Dokumen Sidang-Sidang Federasi Konferensi-Konferensi Para Uskup Se-Asia, op.cit., 9.

34 Dr. Leonardus Samosir, Agama dengan Dua Wajah (Jakarta: Obor, 2010) 69.

35 Riyanto, op.cit., 6.

36 Samosir, op.cit., 71.

37 Ibid., 203. 